\title{
An Empirical Analysis of Exports between Malaysia and TPP Member Countries: Evidence from a Panel Cointegration (FMOLS) Model
}

\author{
Irwan Shah Zainal Abidin ${ }^{1}$, Nor Aznin Abu Bakar ${ }^{1} \&$ Muhammad Haseeb $^{1}$ \\ ${ }^{1}$ Department of Economics, School of Economics Finance and Banking, College of Business Universiti Utara \\ Malaysia, Malaysia \\ Correspondence: Muhammad Haseeb, Department of Economics, School of Economics Finance and Banking, \\ College of Business Universiti Utara Malaysia, Malaysia. E-mail: scholar_economist@yahoo.co.uk
}

Received: September 8, 2014

Accepted: September 20, $2014 \quad$ Online Published: November 8, 2014

doi:10.5539/mas.v8n6p238

URL: http://dx.doi.org/10.5539/mas.v8n6p238

\begin{abstract}
The aim of this study is to investigate empirically the role of Malaysian exports to TPP countries towards economic growth of Malaysia from 1997 to 2012. The results of this study confirm that Malaysian exports to TPP countries contribute in economic growth of Malaysia. Therefore, the result of this study is obtained through the empirical investigation of the model. Mainly, empirical investigation is based on FMOLS model but some preliminary tests are also performed. The results of unit root test presents that all Variables are non-stationary at level I(0) and become stationary after first difference I(1). In addition, results of Kao's panel cointegration shows that all the variables are cointegrated. Furthermore, Results of FMOLS confirms that out of all the variables included in the model, GDP, TRGDP and ER have significant effect on the exports. ECM panel unit root test were applied to confirm the stability of FMOLS. According to the unit root test of the residuals of FMOLS model, it can be confirmed that the long run results are not spurious. Results of Panel ECM show that out of all variables GDP and TRGDP are positively effect on exports. Finally, results of Granger Causality show that only CPI, GDP and TRGDP are cause exports in Malaysia. The government of Malaysia through understood the importance of exports with TPP member countries to boost economic growth. The latter not only contributes to economic growth through capital formation but also promotes trade activity by making financial resources available at lower cost; attracting foreign direct investment as well as facilitating development of advanced technology. Moreover, this study not only contribute to the exports and economic growth literature but also will guide the policy maker to chalk out right, effective and appropriate policy in order to improve exports between Malaysia and TPP countries.
\end{abstract}

Keywords: exports, economic growth, TPP countries, FMOLS, Malaysia

\section{Introduction}

The impact of exports on economic growth has attracted considerable interest from the researchers. The numerous studies have been conducted and found meaningful results between exports and economic growth. Although there is consent among researchers regarding the impact of exports on economic growth but researchers does not show similar consensus during the confirmation of causality among exports and economic growth. The results of causality among exports and economic growth are complex whether exports causing economic growth or economic growth causing exports.

The traditional models of trade prove that trade cause increase in production in the economy. In an open economy, transformation of knowledge and technology is may be due to trade, and there is a shift in resources toward the sectors that draw upon the abundant factors and the value of total production increases. An increase in total output, following a movement from autarky to free trade, can be also found in some models of economies of scale with monopolistic competition Krugman (1979). The neoclassical model presented by Harrod (1939)and Domar (1946) where capital is main factor of production, exports shows positive effect on economic growth in developing country. The Adam Smith (1776), Ricardo (1817) and Solow (1956) admit the importance of exports, and explain that exports can bring an economy at higher level of income since it permits a better allocation of resources. The new growth theories presented by Romer (1986) and more support the contribution of exports in the economic growth. The Grossman and Helpman (1991) explain that, within the new growth theories framework exports boost economic growth through following channels: exports expand the supply of raw 
material and capital equipment, which can enlarge the productivity in the economy. Exports permit developing countries access to improved technology of developed countries in the form of embodied capital goods. Furthermore, exports allow intensification of capacity utilization that increases products produced and consumed (Hamori and Razafimahefa, 2003).

Export is backbone of Malaysian economy since independence. As far as Malaysia's exports is concerned it observed rapid expansion during initial years of 1990s, as it increased from USD 89.66 billion in 1997 to USD 188.74 billion in 2012 (210.54 percent increase in 16 years) due to better exports \& tariff reforms. During the year 1997 to 2012 total exports 2257.32 billion USD and on average 141.08 billion USD was recorded. In 1997 total Malaysian exports 89.66 billion USD, 42.19 billion (47.06 percent) with TPP member countries and 47.46 billion USD (52.93 percent) with non-TPP country was recorded. The highest Malaysian exports volume 188.74 billion USD was recorded in 2012. Similarly, highest export volume with TPP countries 95.37 billion (50.53 percent) was also recorded in 2012. From the total exports of 2257.32 billion, exports with TPP countries 1050.38 billion (46.53 percent) and with non-TPP countries 1206.94 billion (53.46 percent) was recorded during the time period of 1997 to 2012. It can observe that Malaysia is exporting almost 50 percent to 11-TPP member countries. The detail of Malaysian total exports, exports with TPP member countries and with non-TPP countries during the year 1997 to 2012 are presented in Table1.

Table 1. Malaysia Exports with TPP and non-TPP countries

\begin{tabular}{llllll}
\hline Year & $\begin{array}{c}\text { Malaysia Total } \\
\text { Exports (billions } \\
\text { USD) }\end{array}$ & $\begin{array}{c}\text { Malaysia Exports with } \\
\text { TPP countries (billions } \\
\text { USD) }\end{array}$ & $\begin{array}{c}\text { Percentage } \\
\text { From total }\end{array}$ & $\begin{array}{c}\text { Malaysia Exports with } \\
\text { TPP countries (billions } \\
\text { USD) }\end{array}$ & $\begin{array}{c}\text { Percentage } \\
\text { From total }\end{array}$ \\
\hline 1997 & 89.66 & 42.19 & 47.06 & 47.46 & 52.93 \\
1998 & 94.58 & 37.86 & 40.02 & 56.72 & 59.97 \\
1999 & 95.04 & 44.27 & 46.58 & 50.77 & 53.41 \\
2000 & 107.56 & 56.00 & 52.06 & 51.56 & 47.93 \\
2001 & 124.84 & 48.88 & 39.15 & 75.96 & 60.84 \\
2002 & 116.31 & 49.86 & 42.86 & 66.45 & 57.13 \\
2003 & 122.62 & 53.60 & 43.71 & 69.01 & 56.28 \\
2004 & 128.92 & 63.17 & 48.99 & 65.75 & 51.00 \\
2005 & 149.62 & 71.33 & 47.67 & 78.29 & 52.32 \\
2006 & 162.05 & 78.59 & 48.49 & 83.45 & 51.50 \\
2007 & 172.87 & 81.08 & 46.90 & 91.78 & 53.09 \\
2008 & 179.39 & 89.86 & 50.09 & 89.53 & 49.90 \\
2009 & 182.22 & 65.68 & 36.04 & 116.53 & 63.95 \\
2010 & 162.39 & 81.59 & 50.24 & 80.80 & 49.75 \\
2011 & 180.45 & 90.99 & 50.42 & 89.45 & 49.57 \\
2012 & 188.74 & 95.37 & 50.58 & 93.37 & 49.46 \\
\hline
\end{tabular}

Note: data for this table has been taken from IFS CD-ROM data base 2013 and it is authors self calculated.

\section{Review of Literature}

In the literature numerous studies witness the productivity and supply-side effects of exports on domestic output. Increase in domestic output cause increase in capital formation and total factor productivity (TFP) hence economic growth (Krueger 1978). Similarly, Bhagwati (1978) explore that exports support industries which have economics of scale that develop the productivity and efficiency in the long run. Tyler (1981) explores the effect of exports on economic growth in middle income and OPEC member's countries. The study found that exports cause enhancement in technology which leads to increase in absorptive capacity and in cause economic growth. Similarly, Nishimizu and Robinson (1984) investigates that expansion in exports encourage the growth of TFP by increasing competitiveness and economies of scale while expansion in imports discourage the growth of TFP. Theoretical literature on economic growth also support the concept of exports may have positive effect on economic growth in long run. There are several studies (Grossman and Helpman, 1990; Rivera-Batiz and Romer, 1991; Barro and Sala-i-Martin, 1997) explores that export may cause economic growth by transforming technology by importing high-tech import items and from the spillover effects of foreign direct investment. Sachs and Warner (1995) documented that the increase in trade motivates government to initiate a restructuring program to face the competition in open market. Meanwhile, Redding (1999) point out that trade is hurdle in 
economic growth through relative disadvantage in the growth of productivity in specialized sectors of an economy.

In such circumstances, Greenaway et al. (2002) use panel data and shows that with the cause of trade, economic growth increase up to certain level after that it is decline. So, there is $\mathrm{j}$-curve relationship between trade and economic growth. Furthermore, Brunner (2003) considers the model of Frankel and Romer's (1999) and found that due to certain problem effect of trade on economic growth is not robust. On the other hand, Dowrick and Golley (2004) explores that improve in productivity and increase in investment contributes in economic growth but contribution of investment is relatively less as compare to improving productivity. Furthermore, Barro (2003) explore the determinants of economic growth and found that trade is one of the determinants of economic growth The study of Yanikkaya (2003) utilizes annual time series data of 120 countries to investigate the impact of international trade on economic growth. By using two indicators volume of trade and trade restriction on foreign exchange on bilateral payments results conclude that both indicators boost economic growth in long run and short run.

Similarly, Karras (2003) argue that exports improves total factor of productivity and boost economic growth in 105 countries. Further study explains that 1 percent increase in exports cause economic growth increase in between 0.30 percent to 0.35 percent. In addition, Bhattacharya (2011) explore the relationship between FDI, economic growth and volume of merchandize trade. The study explains that FDI have dynamic effects to boost the economic growth, through promote the adoption of modern technology in production sector and encourage the knowledge and training. The transforming knowledge, training and skills into labour cause support the economic growth in case of India. The increase trade leads labor productivity; Alcalà and Ciccone (2004) shows that 1 percent increase in trade cause increase in labor productivity by 1.55 percent hence economic growth.

Same researcher discusses the impact of distance equator and quality of institution. Rassekh (2007) considers Frankel and Romer (1999) growth model and utilizes 150 countries data to investigate the relationship between exports and economic growth. The study argue that less developed countries get more benefits from exports as compared to developed countries due to distance from equator and quality of institutions. Similarly, in literature liberalization indicators presented by Wacziarg and Welch (2003) also discusses. The study of Kneller et al. (2008) argue that country with efficient human capital, less trade taxes and excess supply of raw material for industries can get more benefits from the exports. In addition, Chang and Ying (2008) explore the air freight contribution to boost economic growth in Africa. The results are claim that decrease the cost of air freight, improvement in cargo services has positive and significant effect on economic growth.

Moreover, Kim and Lin (2009) apply instrument-variable threshold regression method on time series data of 61 countries to confirm the contribution of trade in economic growth. The results of the study witness that the relationship exists between trade and economic growth and found a threshold point is USD780 to USD820 per capita. Furthermore, if per capita is less than USD 780 to USD820 than trade is hurt economic growth. In addition, Dufrenote et al. (2010) explains the determinants of economic growth by using quintile regression procedure and found that government balance, inflation, population growth, investment and term of trade are the main determinants of economic growth. Their finding indicates that less develop countries are obtaining more benefits of international trade as compared to developed economies.

Furthermore, Chansomphou and Ichihashi (2011) studies South East Asian countries before and after financial crises to explore the impact of international trade on economic growth. The results of structural break cointegration procedure proposed by Carrion-i-Silvestre and Sano (2006) are indicates that financial crises hurt Malaysian, Indonesian and Pilipino economy whereas Thai economy perform well before and after economic crises in South East Asia. Further results argue that international trade positively affects the output of Malaysian economy and Indonesian economy but effect is smaller in Thai economy, and international trade hasten economic growth in the Pilipino economy before the crisis and after that economic growth is inversely impacted by trade. Moreover, Kim et al. (2011) investigates international trade and economic growth nexuses in less developed countries (LDCs) and developed countries by utilizes threshold regression procedure. The results are shows that in developed countries international trade contributes in growth productivity, capitalization, financial development and economic growth while effect is negative in LDCs.

\section{Data Description and Empirical Methodology}

\subsection{Model Specification}

There are several scholars who study the relationship between export and economic growth (Nie \&Taylo, 2013; Haseeb et al., 2014; Dao, 2014). To investigate the impact of exports on other macroeconomic factor in Malaysia and TPP countries from the year 1997 - 2012 this study employs the specific model followed by pervious 
literature as:

$$
\begin{aligned}
& \ln \text { Export }_{i t}=\alpha_{i}+\beta_{1} \ln G D P_{i t}+\beta_{2} \ln G D P_{j t}+\beta_{3} \ln C P I_{i t}+\beta_{4} \ln C P I_{j t}+\beta_{5} \ln E R_{i t} \\
& +\beta_{6} \ln E R_{j t}+\beta_{7} \ln T R G D P_{i t}+\beta_{8} \ln T R G D P_{j t}+\varepsilon_{t}
\end{aligned}
$$

where:

$\begin{array}{ll}\text { Export }_{\mathrm{it}} & =\text { Exports from country } i \text { to country } j \\ \mathrm{GDP}_{\mathrm{it}} & =\text { Gross Domestic Product of country } i \\ \mathrm{GDP}_{\mathrm{jt}} & =\text { Gross Domestic Product of country } j \\ \mathrm{CPI}_{\mathrm{it}} & =\text { Consumer Price Index of country } i \\ \mathrm{CPI}_{\mathrm{jt}} & =\text { Consumer Price Index of country } j \\ \mathrm{ER}_{\mathrm{it}} & =\text { Real effective Exchange rate of country } i \\ \mathrm{ER}_{\mathrm{jt}} & =\text { Real effective Exchange rate of country } j \\ \mathrm{TRGDP}_{\mathrm{it}} & =\text { Trade Ratio of GDP of country } i \\ \mathrm{TRGDP}_{\mathrm{jt}} & =\text { Trade Ratio of GDP of country } j \\ \mathrm{~B} & =\text { Coefficient } \\ \varepsilon_{\mathrm{t}} & =\text { Error Term }\end{array}$

\subsection{Data Source}

The annual time series data set for 12-TPP countries from the year 1997-2012 is collected from different sources. Data of real GDP, CPI, TRGDP and ER for country i (Malaysia) and country j(TPP countries) taken from World Development Indicator (WDI) database of World Bank. While, data on Exports from country $i$ to country $j$ obtained from the Direction of Trade Statistic, CD-ROM database and website of International Monetary Fund (IMF). Data on the variable GDP, TRGDP and EXPORT are calculated in millions of USD.

\subsection{Methodology}

The main objective of this study is to explore the long-run and short-run relationship of export and other macroeconomic variables of Malaysia and TPP-countries. To test relationship between exports and other macroeconomic variables mainly fully modified least square (FMOLS) were applied. But six different steps were performed to complete the procedure of this model. First, test of stationarity and order of integration among all variables. The study used panel unit root test proposed by Maddala\& Wu (1999), Levin, Lin \& Chu (2002) and Im, Pesaran\& Shin (2003) to determine the stationarity and order of integration. Second, with the assumption that all the variables are in same order of integration stationary at level I (0) or stationary at first difference I(1) Kao panel cointegration proposed by Kao (1999) has been applied to confirm the residual based cointegration among all variables. These tests involve procedures that are designed to detect the presence of a unit root in the residuals of (cointegrating) regressions among the levels of panel data. Third, fully modify ordinary least square (FMOLS) proposed by Pedroni (2000) has been applied to explore the long run relationship between Malaysian export and other variables. Fourth, to confirm that the long run results are not spurious study will applied unit root tests of the residuals of FMOLS model without trend and intercept formation. Fifth, panel error correction model (penal ECM) used to find out short run relationship between all the variables. Finally, after confirm long-run and short-run relationship panel Granger causality will applied to access the direction of causality among all variables.

\subsubsection{Panel Unit Root Test}

In the previous literaturethe unit root tests for the individual time series data (Phillips and Perron (PP) test and Augmented Dickey Fuller test (ADF), and others) are suffering with several problems. One of the main problems is to have low power against the alternative of stationarity of the series, especially if the sample size is small. Panel unit root test have several advantages, it is provide large no of point data, increase the value of degree of freedom and reduce multicollinearity between the two regressors. Moreover, panel unit root test provide us more powerful test statistics asymptotically follow a normal distribution. In this study, Im, Pesaran\&Shin (2003) known as IPS test, Levin, Lin \& Chu (2002) known as LLC test and Maddala\& Wu (1999) known as MW are used. The IPS test is based on the following model: 


$$
\Delta X_{i t}=\alpha_{i}+\beta_{i} X_{i, t-1}+\sum_{k=1}^{n_{i}} \rho_{i j} \Delta X_{i, t-j}+\varepsilon_{i t} i=1, \ldots ., N, \quad t=1, \ldots \ldots, T
$$

where $\Delta$ is the first difference, $X_{i t}$ is the series for Malaysia in the current penal in the time period $t, n_{i}$ is the no of lags and $\varepsilon_{\text {it }}$ is the distributed random variables.

\subsubsection{Panel Cointegration Approach}

The two non-stationary series with the some linear combination said to be cointegrated. In the second step study will applied panel cointegration test proposed by Kao (1999) for the null hypothesis of no cointegration in homogenous and heterogeneous panels. Assumed all variables are I(1), study apply panel cointegration using Kao' (1999) tests. The panel cointegration can be demonstrate as following

$$
X_{i t}=\alpha_{i}+Y_{i t} \beta+\omega_{i t}
$$

where $i=1, \ldots \ldots, N, t=1, \ldots \ldots, T, \varepsilon_{\mathrm{i}}=$ individual constant term, $\beta=$ slop parameter, $\omega_{i}=$ stationary distribution, $\mathrm{X}_{\mathrm{it}}$ and $\mathrm{Y}_{\mathrm{it}}=$ integrated process of order $\mathrm{I}(1)$ for all ${ }_{i}$. Kao (1999) derives two (DF and ADF) types of panel cointegration tests. Both tests can be calculated from:

$$
\varpi_{i t}=\rho \varpi_{i t-1}+V_{i t}
$$

and

$$
\varpi_{i t}=\rho \varpi_{i t-1}+\sum_{i=1}^{\rho} \phi_{j} \Delta \varpi_{i t-j}+V_{i t}
$$

where $\varpi_{i t-1}$ obtained from Equation (2). For null hypothesi部 $H_{O}: \rho=1$ and alternative hypothesis $H_{1}: \rho \angle 1$ is used. Kao (1999) propose four DF-type statistics. The first two DF statistics are based on assuming strict exogenity of the regressors with respect to the error in the equation, while the remaining allow for endogeneity.

\subsubsection{Fully modify ordinary least square (FMOLS)}

The strong evidence allows us to apply FMOLS to confirm the long run relationship among proposed variables. The panel FMOLS have numerous advantages. It allows serial correlation (SE), existence of endogeneity (EE) and cross sectional heterogeneity. Moreover, it will propose both within dimension and between dimensions. Let Equation (2), can obtain the between-dimension Equation (6)

$$
\varpi_{G F M}=N^{-1} \sum_{i=1}^{N}\left[\sum_{t=1}^{T}\left(X_{i t}-X^{\prime}{ }_{i}\right)^{2}\right]^{-1}\left[\sum_{t=1}^{T}\left(X_{i t}-X^{\prime}{ }_{i}\right) Y^{\prime}{ }_{i t}-T r^{\prime}{ }_{i}\right]
$$

where $\varpi_{G F M}=N^{-1} \sum_{i=1}^{N} \varpi_{F M i} \cdot \varpi_{F M i}$ is the FMOLS estimator for individual variable.

\subsubsection{Panel Error Correction Model (Panel ECM)}

Furthermore, study applied panel ECM to explore the short-run relationship among the proposed variables. The study specify panel ECM as follows

$$
\begin{aligned}
& \Delta \ln \text { Export }_{i t}=\mu_{i}+\sum_{j=1}^{11} \delta_{j} D_{j i t}+\sum_{j=1}^{p} \varphi_{1 j} \Delta \ln G D P_{i t-j}+\sum_{j=0}^{p} \phi_{2 j} \Delta \ln G D P_{j t-j}+\sum_{j-1}^{p} \phi_{3 j} \Delta \ln C P I_{i t-j} \\
& +\sum_{j-0}^{p} \phi_{4 j} \Delta \ln C P I_{j t-j}+\sum_{j-0}^{p} \phi_{5 j} \Delta \ln E R_{i t-j}+\sum_{j-0}^{p} \phi_{6 j} \Delta \ln E R_{j t-j}+\sum_{j-0}^{p} \phi_{7 j} \Delta \ln T R G D P_{i t-j} \\
& +\sum_{j-0}^{p} \phi_{8 j} \Delta \ln T R G D P_{j t-j}+\lambda \varepsilon_{i t-1}
\end{aligned}
$$

\subsubsection{Panel Causality}

In the next step study investigate the direction of causality between variables in panel model. According to Engle and Granger (1987) if there are two non-stationary variables are cointegrated, VAR in first difference not be specified. If there is found long-run equilibrium relationship among all variables then study can test Granger Causality with the specified model. The Granger Causality test is based on the following regressions: 
Export Causality

$$
\begin{aligned}
& \Delta \operatorname{Export}_{i t}=C_{1 i}+\sum_{p} \varphi_{11 i p} \Delta \ln G D P_{i t-p}+\sum_{p} \varphi_{12 i p} \Delta G D P_{j t-p}+\sum_{p} \varphi_{13 i p} \Delta C P I_{i t-p}+\sum_{p} \varphi_{14 i p} \Delta C P I_{j t-p} \\
& +\sum_{p} \varphi_{15 i p} \Delta E R_{i t-p}+\sum_{p} \varphi_{16 i p} \Delta E R_{j t-p}+\sum_{p} \varphi_{17 j} \Delta T R G D P_{i t-p}+\sum_{p} \varphi_{18 j} \Delta T R G D P_{j t-p}+\mu_{1 i} E C T_{i t-1}+\varepsilon_{1 t}
\end{aligned}
$$

GDP $_{\mathrm{i}}$ Causality

$$
\begin{aligned}
& \Delta G D P_{i t}=C_{2 i}+\sum_{p} \phi_{21 i p} \Delta \ln E X P O R T_{i t-p}+\sum_{p} \phi_{22 i p} \Delta G D P_{j t-p}+\sum_{p} \phi_{23 i p} \Delta C P I_{i t-p}+\sum_{p} \phi_{24 i p} \Delta C P I_{j t-p} \\
& +\sum_{p} \phi_{25 i p} \Delta E R_{i t-p}+\sum_{p} \phi_{2 \sigma_{i p}} \Delta E R_{j t-p}+\sum_{p} \phi_{27 j} \Delta T R G D P_{i t-p}+\sum_{p} \phi_{28 j} \Delta T R G D P_{j t-p}+\mu_{2 i} E C T_{i t-1}+\varepsilon_{2 t}
\end{aligned}
$$

GDP $_{\mathrm{j}}$ Causality

$$
\begin{aligned}
& \Delta G D P_{j t}=C_{3 i}+\sum_{p} \phi_{31_{i p}} \Delta \ln E X P O R T_{i t-p}+\sum_{p} \phi_{32 i p} \Delta G D P_{i t-p}+\sum_{p} \phi_{33 i p} \Delta C P I_{i t-p}+\sum_{p} \phi_{34 i p} \Delta C P I_{j t-p} \\
& +\sum_{p} \phi_{35 i p} \Delta E R_{i t-p}+\sum_{p} \phi_{36 i p} \Delta E R_{j t-p}+\sum_{p} \phi_{37 j} \Delta T R G D P_{i t-p}+\sum_{p} \phi_{38 j} \Delta T R G D P_{j t-p}+\mu_{3 i} E C T_{i t-1}+\varepsilon_{3 t}
\end{aligned}
$$

$\mathrm{CPI}_{\mathrm{i}}$ Causality

$$
\begin{aligned}
& \Delta C P I_{i t}=C_{4 i}+\sum_{p} 41 \text { iip } \Delta \ln E X P O R T_{i t-p}+\sum_{p} \phi_{42 i p} \Delta G D P_{i t-p}+\sum_{p} \phi_{43 i p} \Delta G D P_{j t-p}+\sum_{p} \phi_{44 i p} \Delta C P I_{j t-p} \\
& +\sum_{p} \phi_{45 i p} \Delta E R_{i t-p}+\sum_{p} \phi_{46 i p} \Delta E R_{j t-p}+\sum_{p} \phi_{47 j} \Delta T R G D P_{i t-p}+\sum_{p} \phi_{48 j} \Delta T R G D P_{j t-p}+\mu_{4 i} E C T_{i t-1}+\varepsilon_{4 t}
\end{aligned}
$$

$C P I_{j}$ Causality

$$
\begin{aligned}
& \Delta C P I_{j t}=C_{5 i}+\sum_{p} \phi_{51 i p} \Delta \ln E X P O R T_{i t-p}+\sum_{p} \phi_{52 i p} \Delta G D P_{i t-p}+\sum_{p} \phi_{53 i p} \Delta G D P_{j t-p}+\sum_{p} \phi_{54 i p} \Delta C P I_{i t-p} \\
& +\sum_{p} \phi_{55 i p} \Delta E R_{i t-p}+\sum_{p} \phi_{56 i p} \Delta E R_{j t-p}+\sum_{p} \phi_{57 j} \Delta T R G D P_{i t-p}+\sum_{p} \phi_{58 j} \Delta T R G D P_{j t-p}+\mu_{5 i} E C T_{i t-1}+\varepsilon_{5 t}
\end{aligned}
$$

$E R_{i}$ Causality

$$
\begin{aligned}
& \Delta E R_{i t}=C_{6 i}+\sum_{p} \phi_{61 i p} \Delta \ln E X P O R T_{i t-p}+\sum_{p} \phi_{62 i p} \Delta G D P_{i t-p}+\sum_{p} \phi_{63 i p} \Delta G D P_{j t-p}+\sum_{p} \phi_{64 i p} \Delta C P I_{i t-p} \\
& +\sum_{p} \phi_{65 i p} \Delta C P I_{j t-p}+\sum_{p} \phi_{66 i p} \Delta E R_{j t-p}+\sum_{p} \phi_{67 j} \Delta T R G D P_{i t-p}+\sum_{p} \phi_{68 j} \Delta T R G D P_{j t-p}+\mu_{6 i} E C T_{i t-1}+\varepsilon_{6 t}
\end{aligned}
$$

$E R_{j}$ Causality

$$
\begin{aligned}
& \Delta E R_{j t}=C_{7 i}+\sum_{p} \phi_{71 i p} \Delta \ln E X P O R T_{i t-p}+\sum_{p} \phi_{72 i p} \Delta G D P_{i t-p}+\sum_{p} \phi_{73 i p} \Delta G D P_{j t-p}+\sum_{p} \phi_{74 i p} \Delta C P I_{i t-p} \\
& +\sum_{p} \phi_{75 i p} \Delta C P I_{j t-p}+\sum_{p} \phi_{76 i p} \Delta E R_{i t-p}+\sum_{p} \phi_{77 i p} \Delta T R G D P_{i t-p}+\sum_{p} \phi_{78 i p} \Delta T R G D P_{j t-p}+\mu_{7 i} E C T_{i t-1}+\varepsilon_{7 t}
\end{aligned}
$$




\section{TRGDP ${ }_{i}$ Causality}

$$
\begin{aligned}
& \Delta T R G D P_{i t}=C_{8 i}+\sum_{p} \phi_{81_{i p}} \Delta \ln E X P O R T_{i t-p}+\sum_{p} \phi_{82 i p} \Delta G D P_{i t-p}+\sum_{p} \phi_{83 i p} \Delta G D P_{j t-p}+\sum_{p} \phi_{84 i p} \Delta C P I_{i t-p} \\
& +\sum_{p} \phi_{85 i p} \Delta C P I_{j t-p}+\sum_{p} \phi_{86} i p \Delta E R_{i t-p}+\sum_{p} \phi_{87 j} \Delta E R_{j t-p}+\sum_{p} \phi_{88 j} \Delta T R G D P_{j t-p}+\mu_{8 i} E C T_{i t-1}+\varepsilon_{8 t}
\end{aligned}
$$

TRGDP Causality

$$
\begin{aligned}
& \Delta T R G D P_{j t}=C_{9 i}+\sum_{p} \phi_{91 i p} \Delta \ln E X P O R T_{i t-p}+\sum_{p} \phi_{92 i p} \Delta G D P_{i t-p}+\sum_{p} \phi_{93 i p} \Delta G D P_{j t-p}+\sum_{p} \phi_{94 i p} \Delta C P I_{i t-p} \\
& +\sum_{p} \phi_{95 i p} \Delta C P I_{j t-p}+\sum_{p} \phi_{96} i p \Delta E R_{i t-p}+\sum_{p} \phi_{97 j} \Delta E R_{j t-p}+\sum_{p} \phi_{98 j} \Delta T R G D P_{i t-p}+\mu_{9 i} E C T_{i t-1}+\varepsilon_{9 t}
\end{aligned}
$$

All variables are previously defined but $\Delta=$ first difference, $\mathrm{ECT}=$ error correction term, $\mathrm{p}=$ lag length, $\mathrm{ECT}_{i t}=$ long-run model estimated residuals from Equation (2), $\mu_{i, j} E C T_{i t}=$ long-run equilibrium.

\section{Empirical Results}

\subsection{Panel Unit Root Test}

To test the panel unit root of each variable $\left(\mathrm{CPI}_{\mathrm{it}}, \mathrm{CPI}_{\mathrm{j}}, \mathrm{ER}_{\mathrm{it}}, \mathrm{ER}_{\mathrm{jt}}, \mathrm{EXPORT}_{\mathrm{it}}, \mathrm{GDP}_{\mathrm{it}}, \mathrm{GDP}_{\mathrm{j}}, \mathrm{TRGDP}_{\mathrm{it}}, \mathrm{TRGDP}_{\mathrm{jt}}\right)$, the test proposed by Maddala\& Wu (1999), Levin, Lin \& Chu (2002) and Im, Pesaran\& Shin (2003) have been applied. The results of panel unit root test reported in Table2. Results are divided into four panels, panel A consists of results from the Levin, Lin \& Chu (2002), panel B consists of the results from Im, Pesaran\& Shin (2003), Panel C consists of the results from ADF Fisher Chi Square and panel D consist of the results from Phillips-Perron (1988) Chi Square. In panel unit root test results are based on majority

Table 2. Unit root test results

\begin{tabular}{llllll}
\hline $\begin{array}{l}\text { Panel A: Levin, } \\
\text { Lin \& Chu Test }\end{array}$ & Level & $\begin{array}{l}\text { First } \\
\text { Difference }\end{array}$ & $\begin{array}{l}\text { Panel B: im, Pesaran\& } \\
\text { Shin W-Test }\end{array}$ & Level & First Difference \\
\hline LNCPIit & 0.0576 & $0.000^{*}$ & LNCPIit & 0.9983 & $0.000^{*}$ \\
LNCPIjt & 0.9684 & $0.000^{*}$ & LNCPIjt & 1.000 & $0.000^{*}$ \\
LNERit & 1.000 & 1.000 & LNERit & 0.0503 & $0.000^{*}$ \\
LNERjt & 0.8927 & $0.000^{*}$ & LNERjt & 0.8950 & $0.000^{*}$ \\
LNEXPORTit & 0.9999 & $0.000^{*}$ & LNEXPORTit & 1.000 & $0.000^{*}$ \\
LNGDPit & 0.9981 & $0.000^{*}$ & LNGDPit & 1.000 & $0.000^{*}$ \\
LNGDPjt & $0.0184^{*}$ & & LNGDPjt & 0.9753 & $0.000^{*}$ \\
LNTRGDPit & 0.9993 & $0.000^{*}$ & LNTRGDPit & 0.9998 & $0.000^{*}$ \\
LNTRGDPjt & 0.1535 & $0.000^{*}$ & LNTRGDPjt & 0.8287 & $0.000^{*}$ \\
Panel C: ADF & Level & First & Panel D: PP Fisher Chi & Level & First Difference \\
Fisher Chi Square & & Difference & Square & & \\
LNCPIit & 1.000 & $0.000^{*}$ & LNCPIit & 1.000 & $0.000^{*}$ \\
LNCPIjt & 1.000 & $0.000^{*}$ & LNCPIjt & 0.9261 & $0.000^{*}$ \\
LNERit & 0.1748 & $0.000^{*}$ & LNERit & $0.000^{*}$ & \\
LNERjt & 0.9185 & $0.000^{*}$ & LNERjt & 0.9397 & $0.000^{*}$ \\
LNEXPORTit & 0.9994 & $0.000^{*}$ & LNEXPORTit & 1.000 & $0.000^{*}$ \\
LNGDPit & 1.000 & $0.000^{*}$ & LNGDPit & 1.000 & $0.000^{*}$ \\
LNGDPjt & 0.5952 & $0.000^{*}$ & LNGDPjt & $0.0109 *$ & \\
LNTRGDPit & 1.000 & $0.000^{*}$ & LNTRGDPit & 1.000 & $0.000^{*}$ \\
LNTRGDPjt & 0.8672 & $0.000^{*}$ & LNTRGDPjt & 0.8204 & $0.000^{*}$ \\
\hline
\end{tabular}

*denoted significant at 1 percent critical value.

According to all four test variables $\mathrm{CPI}_{\mathrm{it}}, \mathrm{CPI}_{\mathrm{j} \mathrm{t}}, \mathrm{ER}_{\mathrm{jt}}, \mathrm{EXPORT}_{\mathrm{it}}, \mathrm{GDP}_{\mathrm{it}}, \mathrm{TRGDP}_{\mathrm{it}}, \mathrm{TRGDP}_{\mathrm{jt}}$ are non-stationary at level and become stationary at first difference. While according to LLC and PP test GDP $_{\mathrm{jt}}$ is stationary at level 
but other two tests IPS and ADF prove it non-stationary at level and stationary at first difference. In this case it is accepted the decision of IPS and ADF as per rule. Furthermore, according to PP test $E_{\mathrm{it}}$ is stationary at level but rest of three tests prove it non-stationary at level and stationary at first difference. Finally, these results shows that most of the variables are stationary at first difference I(1) hence conventional estimation methods of panel data are not applicable here. This study will construct the panel data model method which is robust to First difference I(1) stationary variables.

\subsection{Panel Cointegration Test Results}

As panel unit root test results are concluded that series are integrated with the same order I (1) study proceed to test Cointegration. Thus the second step explores the long-run equilibrium relationship among export and other macroeconomic variables. Results of Kao's Cointegration are reported in Table 3. The results are stated that Export and other proposed variables are cointegrated within the panel of 12-TPP countries.

Table 3. Results of Kao's Residual Cointegration

\begin{tabular}{lll}
\hline Test & $t$-Statistic & P-Value \\
\hline ADF & -6.34367 & 0.0000 \\
\hline
\end{tabular}

Hence according to the $\mathrm{P}$ value, there is Cointegration among the selected set of variables using the Kao residual method.

\subsection{FMOLS Results}

As it is prove that there isCointegration among nine variables Export, GDPi, GDPj, PCGDPi, CPIi, CPIj, ERi, ERj, TRGDPi, TRGDPjstudy further can explore the long-run relationship by Cointegration vector using panel Cointegration techniques. The results of FMOLS are reported in Table 4.

Table 4. FMOLS Test

\begin{tabular}{lllll}
\hline Variables & Coefficient & Std. Error & $t$-Value & $P$-Value \\
\hline LNGDP $_{i}$ & 1034.220 & 12491.64 & 0.082793 & 0.9342 \\
LNGDP $_{j}$ & 19409.22 & 5031.264 & 3.857723 & $0.0002^{*}$ \\
LNTRGDP $_{i}$ & -2533.775 & 10486.69 & -0.230622 & 0.8181 \\
LNTRGDP $j$ & 14386.66 & 4197.542 & 3.427401 & $0.0009^{*}$ \\
LNCPI $_{i}$ & 6725.632 & 4189.256 & 1.605448 & 0.1119 \\
LNCPI $_{j}$ & 143.1625 & 11344.13 & 0.012620 & 0.9900 \\
LNER $_{i}$ & -19100.81 & 4935.385 & -3.870176 & $0.0002^{*}$ \\
LNER $_{j}$ & 6185.669 & 32906.71 & 0.187976 & 0.8513 \\
$*$ denote significant at 5 percent & & \\
\hline
\end{tabular}

These results show that out of all the variables included in the model, GDPj, TRGDPj and ERi has significant effect on the exports.

4.4 ECM Residual Test

After perform FMOLS it is important to confirm the stationary of the model. If the model show non-stationary than it cause spurious regression. The results of ECM residual test are reported in Table5.

Table 5. Results of ECM Residual

\begin{tabular}{cllll}
\hline Test & LEVEL & & \multicolumn{2}{c}{ FIRST DIFFERENCE } \\
\cline { 2 - 5 } & t-statistics & p-values & t-statistic & p-value \\
Levin, Lin \& Chu Test & & & -8.69470 & 0000 \\
& -5.66934 & 0000 & & \\
ADF Fisher Chi Square & 52.7398 & 0000 & 84.6384 & 0000 \\
& & & & \\
PP Fisher Chi Square & 52.7705 & 0000 & 98.6815 & 0000 \\
\hline
\end{tabular}


According to the unit root test of the residuals of FMOLS model without trend and intercept formation, it can be confirmed that the long run results are not spurious.

\subsection{Panel ECM Model}

After confirmed the long-run relationship panel ECM were applied to explore the short-run relationships among all variables. Results of panel ECM are reported in Table6.

Table 6. Results of Panel ECM (dependent variable $\Delta$ LNEXPORT)

\begin{tabular}{|c|c|c|c|c|}
\hline Variables & Coefficient & Std. Error & $t$-Value & $P$-Value \\
\hline$\Delta \mathrm{LNGDP}_{i}$ & 3337.553 & 30825.97 & 0.108271 & 0.9140 \\
\hline$\Delta \mathrm{LNGDP}_{j}$ & 5422.133 & 776.0105 & 6.987190 & $0.0000^{*}$ \\
\hline$\Delta$ LNTRGDP $_{i}$ & 7984.238 & 25313.50 & 0.315414 & 0.7532 \\
\hline$\Delta$ LNTRGDP $j$ & 8724.970 & 1439.374 & 6.061642 & $0.0000 *$ \\
\hline$\Delta \mathrm{LNCPI}_{i}$ & 18917.59 & 79632.86 & 0.237560 & 0.8128 \\
\hline$\Delta \mathrm{LNCPI}_{j}$ & -10174.19 & 14194.78 & -0.716756 & 0.4754 \\
\hline$\Delta \mathrm{LNER}_{i}$ & 1311.870 & 29019.46 & 0.045207 & 0.9640 \\
\hline$\Delta \mathrm{LNER}_{j}$ & 13908.80 & 7103.291 & 1.958078 & 0.0534 \\
\hline $\operatorname{ECM}(-1)$ & 0.524339 & 0.397569 & 1.318865 & $0.0406 *$ \\
\hline $\mathrm{C}$ & -414788.3 & 508470.9 & -0.815756 & 0.4168 \\
\hline
\end{tabular}

*denote significant at 5 percent.

According to the short run results, it is anticipated that that there is convergence in the long run equilibrium which is depicted by table 5 . If there is 1percent disequilibrium then exports will respond 0.52 percent each time period to restore the equilibrium. Hence it takes 1.92 time periods to restore the equilibrium. From the short run variables it is observed that there are GDP and CPIpositively causing exports in short run.

\subsection{Panel Granger Causality Tests}

Granger Causality test were applied to confirmed the direction of causality of all variables. The results of Granger Causality are tabulated in Table6.

Table 7. Results of Granger Causality

\begin{tabular}{|c|c|c|c|c|}
\hline Direction of Causality & p-value & Lags & Decision & Outcome \\
\hline $\mathrm{ER}_{\mathrm{j}}>$ EXPORT & 0.6064 & 2 & Does not reject null & $E_{\mathrm{j}}$ does not cause Export \\
\hline EXPORT $>$ ER $_{j}$ & 0.8698 & 2 & Does not reject null & Export does not cause $\mathrm{ER}_{\mathrm{j}}$ \\
\hline $\mathrm{ER}_{\mathrm{i}}>\mathrm{EXPORT}^{\prime}$ & 0.3087 & 2 & Does not reject null & ER $_{\mathrm{i}}$ does not cause Export \\
\hline EXPORT $>$ ER $_{i}$ & 0.0959 & 2 & Does not reject null & Export does not cause $\mathrm{ER}_{\mathrm{i}}$ \\
\hline $\mathrm{CPI}_{\mathrm{i}}>\mathrm{EXPORT}$ & $0.0029 *$ & 2 & Reject null & $\mathrm{CPI}_{\mathrm{i}}$ does cause Export \\
\hline EXPORT $>\mathrm{CPI}_{\mathrm{i}}$ & 0.7627 & 2 & Does not reject null & Export does not cause $\mathrm{CPI}_{\mathrm{i}}$ \\
\hline $\mathrm{CPI}_{\mathrm{j}}>\mathrm{EXPORT}$ & 0.1503 & 2 & Does not reject null & $\mathrm{CPI}_{\mathrm{j}}$ does not cause Export \\
\hline EXPORT $>\mathrm{CPI}_{\mathrm{j}}$ & 0.5998 & 2 & Does not reject null & Export does not cause $\mathrm{CPI}_{\mathrm{i}}$ \\
\hline $\mathrm{GDP}_{\mathrm{i}}>$ EXPORT & 0.7099 & 2 & Does not reject null & GDP $_{\mathrm{i}}$ does not cause Export \\
\hline EXPORT $>\mathrm{GDP}_{\mathrm{i}}$ & 0.4036 & 2 & Does not reject null & Export does not cause GDP ${ }_{i}$ \\
\hline GDP $_{\mathrm{j}}>$ EXPORT & 0.2686 & 2 & Does not reject null & GDP $_{\mathrm{j}}$ does not cause Export \\
\hline EXPORT $>\mathrm{GDP}_{\mathrm{j}}$ & $0.0001 *$ & 2 & Reject null & Export does cause $\mathrm{GDP}_{\mathrm{j}}$ \\
\hline TRGDP $_{\mathrm{i}}>$ EXPORT & 0.0566 & 2 & Does not reject null & TRGDP $_{\mathrm{i}}$ does not cause Export \\
\hline 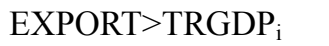 & $0.0028 *$ & 2 & Reject null & Export does cause TRGDP ${ }_{i}$ \\
\hline TRGDP $_{\mathrm{j}}>\mathrm{EXPORT}$ & 0.0715 & 2 & Does not reject null & TRGDP $_{j}$ does not cause Export \\
\hline 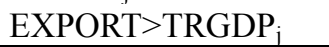 & 0.2519 & 2 & Does not reject null & Export does not cause TRGDP $_{\mathrm{j}}$ \\
\hline
\end{tabular}

*denoted significant at 5\% critical value.

Using the granger causality test it is confirm that only CPI, GDP and TRGDP are significantly causing exports. 


\section{Conclusion and Policy Implication}

The purpose of this study is to confirm the Malaysia - TPP countries exports contribution towards the economic growth of Malaysia. The results are confirmed that Malaysia-TPP countries exports contribute in Malaysian economic growth. Therefore, the result of this study is obtained through the empirical investigation of the model. Mainly, empirical investigation is based on FMOLS model but some preliminary tests are also performed to fulfill the assumptions of FMOLS. Before applying FMOLS, it is necessary to confirm the order of integration and stationarity $\mathrm{I}(0)$ or $\mathrm{I}(1)$ of each variable. Results show that all Variables are non-stationary at level $\mathrm{I}(0)$ and become stationary after first difference I(1). These results were obtained by utilizing panel unit root tests proposed by Maddala\& Wu (1999), Levin, Lin \& Chu (2002) and Im, Pesaran\& Shin (2003). In addition, the results of Panel co-integration were shown that there is Cointegration among all variable and the null hypothesis of no Cointegration is rejected. Results of FMOLS shows that out of all the variables included in the model, GDP, TRGDP and ER have significant effect on the exports. ECM panel unit root test were applied to confirm the stability of FMOLS. According to the unit root test of the residuals of FMOLS model without trend and intercept formation, it can be confirmed that the long run results are not spurious. Results of Panel ECM show that out of all variables GDP and TRGDP are positively effect on exports. Finally, results of Granger Causality show that only CPI, GDP and TRGDP have causality with exports of Malaysia.

The findings of this study are consistent with Ghatak, Milner, and Utkulu (1997), Al-Yousif (1999), Khalafalla and Webb (2001) and Haseeb et al. (2014) in case of Malaysia and lends support to the view of Romer (1990), Edwards (1989), Villanueva (1994), Edwards (1992), Wacziarg and Welch (2003) and Yanikkaya (2003). However the finding contrasts with that of Hye (2011) who finds that export is hurdle for economic growth. In case of Malaysia- TPP the exports have meaningful effect on economic growth of Malaysia and government of Malaysia should focus more on exports with TPP member's countries. The latter not only contributes to economic growth through capital formation but also promotes exports activity by making financial resources available at lower cost; attracting foreign direct investment as well as facilitating development of advanced technology.

\section{References}

Alcalà, F., \& Ciccone, A. (2004). Trade and productivity. Quarterly Journal of Economics, 119, 612-645.

Barro, R. (2003). Determinants of economic growth in a panel of countries. Annals of Economics and Finance, 4, 231-274.

Barro, R. J., \& Sala-i-Martin, X. (1995). Technological diffusion, convergence and growth. CEPR Discussion Papers 1255, C.E.P.R. Discussion Papers.

Bhagwati, J. N. (1978). Anatomy and Consequences of Exchange Control Regimes. A Special Conference Series on Foreign Trade Regimes and Economic Development, 11(11). Cambridge, MA, Ballinger.

Bhattacharya, M. (2011). Foreign direct investment inflow, merchandize trade and economic growth in India: An analytical study. International Journal of Finance and Policy Analysis, 3(1), 36-49.

Brunner, A. D. (2003). The long-run effects of trade on income and income growth (pp. 3-37). IMF Working Paper.

Carrion-i-Silvestre, J., \& Sanso, A. (2006). Testing the null of cointegration with structural breaks. Oxford Bulletin of Economics and Statistics, 68, 642-646.

Chang, C. P., \& Ying, Y. H. (2008). The generative power of air freight in the trade openness economic Bulletin, 31, 2890-2902.

Chansomphou, V., \& Ichihashi, M. (2011). The impact of trade openness on the incomes of four South East Asian countries before and after the Asian financial crisis. Economics countries. Journal of Development Economics, 30, 93-102.

Dao, M. (2014). Exports, imports, government consumption and economic growth in upper-middle income countries. Progress In Development Studies, 14(2), 197-204. http://dx.doi.org/10.1177/1464993413517791

Domar, E. D. (1946). Capital Expansion, Rate of Growth, and Employment. Econometrica, 14(2), 137-147. http://dx.doi.org/ 10.2307/1905364

Dowrick, S., \& Golley, J. (2004). Openness and growth: who benefits? Oxford Review of Economic Policy, 20, $38-56$.

Dufrenot, G., Mignon, V., \& Tsangarides, C. (2010). The trade-growth nexus in the developing countries: A 
quantile regression approach. Review of World Economics, 146, 731-761.

Edwards, S. (1989). Trade orientation, distortions and growth in developing economies. Journal of Development Economics, 31, 31-57.

Edwards, S. (1992). Trade orientation, distortions and growth in developing countries. Journal of Development Economics, 39, 31-57.

Engle, R. F., \& Clive, W. J. G. (1987). Cointegration and Error Correction Representation: Estimation and Testing. Econometrica, 55(2), 251-276.

Frankel, J., \& Romer, D. (1999). Does trade cause convergence. American Economic Review, 89, 379-399.

Ghatak, S., Milner, C., \& Utkulu, U. (1997). Exports, export composition and growth: Cointegration and causality evidence for Malaysia. Applied Economics, 29(2), 213-223. http://dx.doi.org/ $10.1080 / 000368497327272$

Greenaway, D., Morgan, C. W., \& Wright, P. W. (2002). Trade liberalisation and growth: New methods, new evidence. Journal of Development Economics, 67, 229-244.

Grossman, G. M., \& Helpman, E. (1991). Growth and Welfare in a Small Open Economy. In E. Helpman, \& A. Razin (Eds.), International Trade and Trade Policy (pp. 141-163). MIT Press, Cambridge, MA.

Hamori, S., \& Razafimahefa, I. F. (2003). Trade and Growth Relationship: Some Evidence from Comoros, Madagascar, Mauritius and Seychelles. Asian African Area Studies, 3(4), 174-186.

Harrod, R. F. (1939). An Essay in Dynamic Theory. The Economic Journal, 49(193), 14-33. http://dx.doi.org/ $10.2307 / 2225181$.

Haseeb, M., Hartani., N. H., Abu-Bakar, N. A., Azam, M., \& Hassan, S. (2014). Exports, foreign direct investment and economic growth: Empirical evidence from Malaysia (1971-2013). American Journal of Applied Sciences, 11(6), 1010-1015. Http://dx.doi.org/ 10.3844/ajassap.2014.1010.1015.

Hye, Q. M. A. (2011). Long run effect of trade openness on economic growth in case of Pakistan. Quality and Quantity. http://dx.doi.org/10.1007/s11135-011-9612-0.

Im, K. S., Pesaran, M. H., \& Shin, Y. (2003). Testing for unit roots in heterogeneous panels. Journalof Econometrics, 115, 53-74.

Kao, Chihwa. (1999). Spurious regression and residual-based tests for cointegration in panel data. Journal of Econometrics, 90(1), 1-44.

Karras, G. (2003). Trade openness and economic growth: Can we estimate the precise effect? Applied Econometrics and International Development, 3, 7-24.

Khalafalla, K. Y., \& Webb, A. J. (2001). Export-led growth and structural change: Evidence from Malaysia. Applied Economics, 33(13), 1703-1715. http://dx.doi.org/ 10.1080/00036840010015066

Kim, D. H., \& Lin, S. C. (2009). Trade and growth at different stages of economic development. Journal of Development Studies, 45, 1211-1224.

Kim, D. H., Lin, S. C., \& Suen, Y. B. (2011). Nonlinearity between trade openness and economic development. Review of Development Economics, 15, 279-292.

Kneller, R., Morgan, C. W., \& Kanchanahatakij, S. (2008). Trade liberalisation and economic growth. The World Economy, 31, 701-719.

Krueger, A. O. (1978). Foreign trade regimes and economic development: Liberalization attempts and consequences (Ballinger, Cambridge, MA). Krueger Foreign Trade Regimes and Economic Development: Liberalisation Attempts and Consequences 1978.

Krugman, P. R. (1979). Increasing returns, monopolistic competition, and international trade. Journal of International Economics, 9(4), 469-479. http://dx.doi.org/ http://dx.doi.org/10.1016/0022-1996(79)90017-5

Levin, A., Chien, F. L., \& Chia, S. J. C. (2002). Unit root tests in panel data: asymptotic and finite sample properties. Journal of Econometrics, 108(1), 1-24.

Lucas, R. E. (1988). On the mechanics of economic development. Journal of Monetary Economics, 22, 3-42.

Maddala, G. S., \& Wu, S. (1999). A Comparative Study of Unit Root Tests with Panel Data and A New Simple Test. Oxford Bulletin of Economics and Statistics, 61, 631-52. 
Nie, J., \& Taylor, L. (2013). Economic growth in foreign regions and U.S. export growth. Economic Review (01612387), 31-63.

Nishimizu, M., \& Robinson, S. (1984). Trade policies and productivity change in semiindustrialized.

Pedroni, P. (2004). Panel cointegration: Asymptotic and finite sample properties of pooled time series tests with an application to the PPP hypothesis. Econometric Theory, 20, 597-625.

Phillips, P., \& Perron, P. (1988). Testing for a unit root in time series regression. Biometrica, 75(3), 335-346.

Rassekh, F. (2007). Is international trade more beneficial to lower income economies? An empirical inquiry. Review of Development Economics, 11, 159-169.

Redding, S. (1999). Dynamic comparative advantage and the welfare effects of trade. Oxford Economic Papers, $51,15-39$.

Rivera-Batiz, L. A., \& Romer, P. M. (1991). International trade with endogenous technological change. European Economic Review, 35, 971-1001.

Romer, P. M. (1986). Increasing Returns and Long-Run Growth. Journal of Political Economy, 94(5), 1002-1037. http://dx.doi.org/ 10.2307/1833190

Romer, P. M. (1990). The problem of development: a conference of the institute for the study of free enterprise system. Journal of Political Economy, 98, 1-11.

Solow, R. M. (1956). A Contribution to the Theory of Economic Growth. The Quarterly Journal of Economics, 70(1), 65-94. http://dx.doi.org/ 10.2307/1884513

Tyler, W. J. (1981). Growth and exports expansion in developing economies: Some empirical evidence. Journal of Development Economics, 9, 121-130.

Villanueva, D. (1994). Openness, human development and fiscal policies. IMF Staff Papers, 41, 1-29.

Wacziarg, R., \& Welch, K. H. (2003). Trade liberalization and growth: new evidence. Working Paper No. 10152. National Bureau of Economic Research, Washington, DC.

Yanikkaya, H. (2003). Trade openness and economic growth: a cross country empirical investigation. Journal of Development Economics, 72, 57-89.

\section{Copyrights}

Copyright for this article is retained by the author(s), with first publication rights granted to the journal.

This is an open-access article distributed under the terms and conditions of the Creative Commons Attribution license (http://creativecommons.org/licenses/by/3.0/). 